\title{
ASSESSMENT OF STUDENT'S INTERESTS AND TALENTS USING THE WEB-BASED CERTAINTY FACTOR METHOD
}

\author{
${ }^{(*) 1}$ Satryanto Andi Seputro, ${ }^{2}$ Fajar Masya \\ 1,2Program Studi Sistem Informasi, Universitas Mercu Buana Jakarta \\ www.mercubuana.ac.id \\ email: 1andiseputro@gmail.com,2fajar.masya@mercubuana.ac.id \\ (*) Corresponding Author
}

\begin{abstract}
Abstrak
Dalam rangka meningkatkan kecerdasan seorang anak, dapat dimulai dari mengetahui keunggulan yang dimiliki anak pada aspek kecerdasan majemuk dengan cara menggali minat dan bakat anak sedini mungkin agar dapat berkembang secara optimal. Pada TK Widya Bhakti sulit untuk mengetahui minat dan bakat siswa karena tidak tersedianya perlengkapan penilaian. Oleh karena itu dilakukan penelitian dengan menggunakan aplikasi berbasis web bernama AMIBA yang dapat digunakan untuk mengetahui minat dan bakat siswa tersebut. Metode yang dipergunakan dalam penelitian ini adalah metode Certainty Factor yang dapat mengukur tingkat kepastian. Hasil penelitian menunjukkan bahwa aplikasi ini dapat melakukan penilaian terhadap minat dan bakat yang dimiliki oleh setiap siswa.
\end{abstract}

Kata kunci: Sistem Pakar, Faktor Kepastian, Minat dan Bakat Anak

\begin{abstract}
To improves a child's intelligence, it can be started from knowing the advantages possessed by children in the aspect of multiple intelligences by exploring the interests and talents of children as early as possible to develop optimally. At TK Widya Bhakti it is difficult to know the interests and talents of students because of the unavailability of assessment equipment. Therefore a study was conducted using a web-based application called AMIBA that can be used to determine the interests and talents of these students. The method used in this study is the Certainty Factor method that can measure the level of certainty. The results showed that this application can assess the interests and talents possessed by each student.
\end{abstract}

Keywords: Expert Systems, Certainty Factor, Children's Interest and Talent

\section{PRELIMINARY}

The use of computer applications in the modern era is growing rapidly, one of which is in the field of psychology where an application can be developed regarding interests and talents in early childhood. As is known the potential, interests, and talents that are owned by each child are not the same. Potential is a basic ability such as specific things possessed by a child, interest is one's desire to choose something is favored while talent can be interpreted as intelligence and innate abilities that exist from birth (Komala, 2017). The important thing in increasing the intelligence of a child is done by parents and teachers is that they must know the child's potential in advance by recognizing the interests and talents of children to develop optimally. Thus parents and teachers can direct and guide according to the interests and talents of the child.
Widya Bhakti Kindergarten is a place of learning and playing for young children aged 4-5 years. This school has not implemented the assessment of students' interests and talents, because there are no appraisal tools available to determine their interests and talents. Therefore, a study using a web-based application called AMIBA can be used to determine the interests and talents of these students.

This study translates the theory of the Nine Multiple Intelligences discovered by Howard Gardner viz (1) Word Smart (Linguistic); (2) Numbering/Reasoning Smart (LogicalMathematical); (3) Picture Smart (Spatial); (4) Body Smart (Bodily-Kinesthetic); (5) Sound Smart (Musical); (6) People Smart (Interpersonal); (7) Self Smart (Intra-Personal); (8) Nature Smart (Naturalist) and Life Smart (Existential)(Musfiroh, 2014). Multiple intelligence is the initial stage in knowing the interests and talents of a child, with multiple intelligences showing that every child has 
the potential to be developed optimally if stimulated properly. Early childhood is the most appropriate to know the potential for intelligence because it is a golden age that develops physical, psychological, and psychological quickly(Educenter, 2018).

This theory became the basis for making this application to assess student's interests and talents. The application implements an expert system, which is the expertise performance of an expert adopted into a computer program and can be used in decision making using the Certainty Factor method, a value to measure expert confidence(Andriani, 2016). Equipped with the PHP programming language and MySQL as a database processor. Explanation of how the system works. (1) Admin experts enter student interests by the characteristics of the nine theories of multiple intelligences, based on these interests the system will process calculations using Certainty Factor; (2) User can do an assessment of interests and talents. At the end of the assessment, a conclusion will be obtained in the form of student talent output. Besides, in the post statement about the application of interests and talents, there is stimulation and advice regarding the potential direction of students so that they can develop as early as possible.

The Certainty Factor method is defined as follows:

$$
\mathrm{CF}[\mathrm{h}, \mathrm{e}]=\mathrm{MB}[\mathrm{h}, \mathrm{e}]-\mathrm{MD}[\mathrm{h}, \mathrm{e}]
$$

\section{Where:}

CF $[\mathbf{h}, \mathbf{e}]=$ Certainty Factor in the hypothesis $\mathbf{h}$ due to evidence $\mathbf{e}$.

$\mathbf{M B}[\mathbf{h}, \mathbf{e}]=$ Measure of Believe is the measure of increased belief in $\mathbf{h}$ due to $\mathbf{e}$.

MD[h,e] = Measure of Disbelieve is the measure of increased disbelief in $\mathbf{h}$ due to $\mathbf{e}$.

$\mathbf{h}=$ Hypothesis

$\mathbf{e}=$ Evidence

The following are examples of certainty factor assessment in the application of interests and talents:

Child behavior likes to read, certainty factor assessment:

$$
\begin{array}{ll}
\mathrm{MB}[\mathrm{h}, \mathrm{e}] & =0,8 \\
\mathrm{MD}[\mathrm{h}, \mathrm{e}] & =0,2 \\
\mathrm{CF}[\mathrm{h}, \mathrm{e}] & =0,8-0,2 \\
& =0,6 \text { "Most likely" }
\end{array}
$$

Where:

Interest in children like to read tend Linguistic talent with value $\mathbf{C F}=\mathbf{0 , 6}$.
The use of expert systems or the certainty factor method has been applied by other researchers as follows:

The first research explaining the problem at hand is the lack of specific guidance from parents and teachers in Indonesia about children's talents and interests which results in stunted student development. The purpose of this study is to optimize the development of self-potential regarding the advantages and disadvantages of students and teachers can easily group and determine the treatment of the development of the talents and interests of students. The method applied in the case study uses the certainty factor method. Determination of interest and talent criteria you can do in this application which is the result of research(Rachman \& Mukminin, 2018).

The second research that explains the problem faced is students in grades IV until VI Elementary School do not understand their potential, whether it's weaknesses or strengths. The purpose of this research is that interest and talent students in grades IV through VI who are around 10 and 11 years old can be determined. Predicting the interests of student talent IV until VI can be done in this application using the case-based reasoning method whose results are prediction based on (similarity)(Yulianti, 2016).

The third research explains the problem at hand is elementary school students aged 6 to 12 years of interest and talent cannot yet be known. The purpose of this study is that students' skills in terms of academics or personality can be known. The method used is Forward Chaining. The intelligence of students' interests and talents can be determined by the system that has been created, along with information about the stimulation of the types of interests and talents(Salisah et al., 2015).

The fourth research that explains this problem is that the tour packages are still not manually using an application, the information is unknown to tourists. The purpose of this research is to develop a decision support system. The method used is the Technique for Order Preference by Similarity to Ideal Solution (TOPSIS) method. The ability to select alternative travel package options is the result of a research decision support system. In effect, the customer can choose travel packages immediately.(Ardha et al., 2019).

\section{RESEARCH METHODS}

Data collection methods in this research are (1) Direct observation to Widya Bhakti Kindergarten; (2) Interviews with teachers about teaching and learning activities related to interests and talents 
and experts in the field of psychology; (3) A literature study is taking information from books, journals, articles, and the internet.

The research process through the stages and steps as follows:

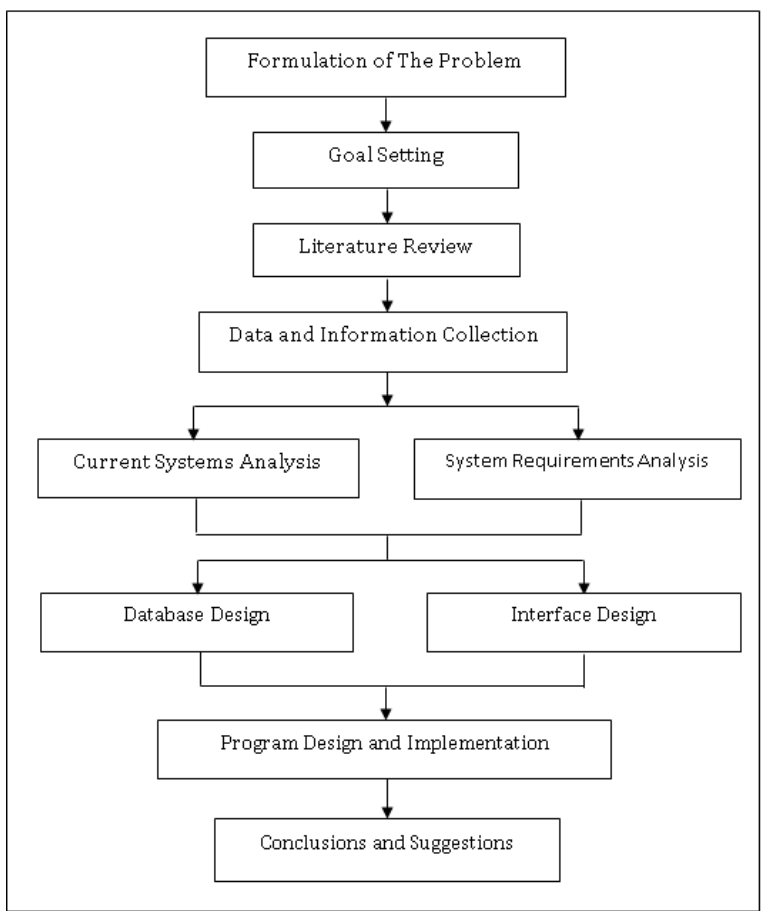

Figure 1 Research Flow Chart

Explanation of the research flow diagram above, i.e (1) the first stage is formulating the problem; (2) the second stage determines the purpose of research so that problems that occur get appropriate and useful solutions; (3) a literature study is a stage that was done to increase knowledge about the problems discussed and to determine the theory and research methods that are appropriate in solving problems that occur. Researchers use books, journals, articles, and pages related to the research.; (4) collecting data and information that is establishing data and information as a source of data besides interview and observation techniques in the field is a step taken in the use of primary data; (5) system analysis is a stage of system analysis starting from running system analysis and analyzing system requirements, namely comparing the running business processes with the system requirements to be made; (6) database design and interface design related to mockup; (7) the program design stage related to the system output and input design and then system implementation; (8) research results and discussion viz summary of decisions resulting from research

\section{RESEARCH RESULTS AND DISCUSSION}

In determining interests and talents, required assessment using the certainty factor method by existing trends in the application of interests and talents. Settings using admin login by adding interest and talent data then input value Measure of Believe and Measure of Disbelieve.

Furthermore, the certainty factor will process assess to get the value of certainty of the interests that produce the talents of the students.

The Certainty factor assessment table is to facilitate the presentation of data.

Table 1 Assessment of Certainty Factor

\begin{tabular}{|c|c|c|c|c|c|c|}
\hline CF Code & Interests & MB & MD & CF & Term & Talents \\
\hline G01 & Like to read & 0,8 & 0,2 & 0,6 & Most likely to & Linguistic \\
\hline G02 & Like to write & 0,8 & 0,4 & 0,4 & Maybe & Linguistic \\
\hline G03 & Love to tell stories & 1,0 & 0,2 & 0,8 & Almost certain & Linguistic \\
\hline G04 & Talkative & 1,0 & 0,2 & 0,8 & Almost certain & Linguistic \\
\hline G05 & Easy to understand new words & 1,0 & 0,0 & 1,0 & Certainly & Linguistic \\
\hline G06 & Like to argue with other people & 1,0 & 0,2 & 0,8 & Almost certain & Linguistic \\
\hline G07 & Like to make speeches & 1,0 & 0,2 & 0,8 & Almost certain & Linguistic \\
\hline G08 & Like to count & 1,0 & 0,0 & 1,0 & Certainly & Logical-Mathematical \\
\hline G09 & Like to count numbers & 1,0 & 0,0 & 1,0 & Certainly & Logical-Mathematical \\
\hline G10 & Like to use formulas & 1,0 & 0,0 & 1,0 & Certainly & Logical-Mathematical \\
\hline G11 & Love games like chess & 0,8 & 0,2 & 0,6 & Most likely to & Logical-Mathematical \\
\hline G12 & Prefer to explain the purpose with pictures & 0,8 & 0,2 & 0,6 & Most likely to & Logical-Mathematical \\
\hline G13 & Like to think scientifically & 1,0 & 0,2 & 0,8 & Almost certain & Logical-Mathematical \\
\hline G14 & Like to do research or trials & 0,8 & 0,0 & 0,8 & Almost certain & Logical-Mathematical \\
\hline G15 & Easy to understand the story & 0,8 & 0,2 & 0,6 & Most likely to & Logical-Mathematical \\
\hline G16 & Loves to Paint & 1,0 & 0,0 & 1,0 & Certainly & Spatial \\
\hline G17 & Likes to play with shapes and spaces & 0,8 & 0,0 & 0,8 & Almost certain & Spatial \\
\hline G18 & Love to take pictures & 0,6 & 0,2 & 0,4 & Maybe & Spatial \\
\hline G19 & Loves to play puzzle & 0,8 & 0,2 & 0,6 & Most likely to & Spatial \\
\hline G20 & Easily recognize shapes & 1,0 & 0,0 & 1,0 & Certainly & Spatial \\
\hline G21 & Like to imagine & 1,0 & 0,2 & 0,8 & Almost certain & Spatial \\
\hline G22 & Like to sketch & 1,0 & 0,0 & 1,0 & Certainly & Spatial \\
\hline G23 & Love gymnastics & 0,8 & 0,2 & 0,6 & Most likely to & Bodily-Kinesthetic \\
\hline
\end{tabular}




\begin{tabular}{|c|c|c|c|c|c|c|}
\hline CF Code & Interests & MB & MD & CF & Term & Talents \\
\hline G24 & Like to dance & 0,8 & 0,2 & 0,6 & Most likely to & Bodily-Kinesthetic \\
\hline G25 & $\begin{array}{l}\text { Active in physical activities such as } \\
\text { swimming }\end{array}$ & 0,8 & 0,2 & 0,6 & Most likely to & Bodily-Kinesthetic \\
\hline G26 & Like to exercise martial arts & 0,8 & 0,2 & 0,6 & Most likely to & Bodily-Kinesthetic \\
\hline G27 & Loves to play drama & 0,8 & 0,4 & 0,4 & Maybe & Bodily-Kinesthetic \\
\hline G28 & Likes to imitate the motion & 1,0 & 0,0 & 1,0 & Certainly & Bodily-Kinesthetic \\
\hline G29 & Prominent in sports subjects & 1,0 & 0,0 & 1,0 & Certainly & Bodily-Kinesthetic \\
\hline G30 & Like and can play musical instruments & 0,8 & 0,2 & 0,6 & Most likely to & Musical \\
\hline G31 & Like to sing & 1,0 & 0,0 & 1,0 & Certainly & Musical \\
\hline G32 & Loves to listen to songs & 1,0 & 0,2 & 0,8 & Almost certain & Musical \\
\hline G33 & Can create or compose songs & 0,8 & 0,2 & 0,6 & Most likely to & Musical \\
\hline G34 & Easy to understand the rhythm of the song & 1,0 & 0,0 & 1,0 & Certainly & Musical \\
\hline G35 & $\begin{array}{l}\text { More able to learn with the accompaniment } \\
\text { of songs }\end{array}$ & 0,8 & 0,2 & 0,6 & Most likely to & Musical \\
\hline G36 & Likes to give advice to others & 1,0 & 0,2 & 0,8 & Almost certain & Interpersonal \\
\hline G37 & Like to discuss & 0,8 & 0,2 & 0,6 & Most likely to & Interpersonal \\
\hline G38 & Glad to be among many people & 1,0 & 0,2 & 0,8 & Almost certain & Interpersonal \\
\hline G39 & Nice to meet new people & 1,0 & 0,0 & 1,0 & Certainly & Interpersonal \\
\hline G40 & Able to be a leader for his friends & 0,8 & 0,4 & 0,4 & Maybe & Interpersonal \\
\hline G41 & Happy listening to his friends tell stories & 1,0 & 0,0 & 1,0 & Certainly & Interpersonal \\
\hline G42 & Likes to teach something new to his friends & 0,8 & 0,2 & 0,6 & Most likely to & Interpersonal \\
\hline G43 & Easy to control emotions & 0,8 & 0,2 & 0,6 & Most likely to & Intra-Personal \\
\hline G44 & Like with calm & 0,8 & 0,2 & 0,6 & Most likely to & Intra-Personal \\
\hline G45 & plan on a personal agenda & 1,0 & 0,2 & 0,8 & Almost certain & Intra-Personal \\
\hline G46 & Circumstances that are easily expressed & 0,8 & 0,2 & 0,6 & Most likely to & Intra-Personal \\
\hline G47 & $\begin{array}{l}\text { Like to contemplate or think about life or } \\
\text { yourself }\end{array}$ & 1,0 & 0,0 & 1,0 & Certainly & Intra-Personal \\
\hline G48 & Likes to study alone & 1,0 & 0,2 & 0,8 & Almost certain & Intra-Personal \\
\hline G49 & Have high self confidence & 1,0 & 0,0 & 1,0 & Certainly & Intra-Personal \\
\hline G50 & Love caring for plants & 1,0 & 0,0 & 1,0 & Certainly & Naturalist \\
\hline G51 & Loves to keep pets & 0,8 & 0,2 & 0,6 & Most likely to & Naturalist \\
\hline G52 & Happy to go out in nature & 1,0 & 0,2 & 0,8 & Almost certain & Naturalist \\
\hline G53 & Like gardening & 1,0 & 0,0 & 1,0 & Certainly & Naturalist \\
\hline G54 & Loves camping & 0,8 & 0,2 & 0,6 & Most likely to & Naturalist \\
\hline G55 & Caring about the environment & 1,0 & 0,0 & 1,0 & Certainly & Naturalist \\
\hline G56 & Have high self- awareness & 1,0 & 0,2 & 0,8 & Almost certain & Existential \\
\hline G57 & $\begin{array}{l}\text { More likely to prioritize the interests of } \\
\text { belief (religion) }\end{array}$ & 1,0 & 0,0 & 1,0 & Certainly & Existential \\
\hline G58 & Internally motivated & 0,8 & 0,2 & 0,6 & Most likely to & Existential \\
\hline G59 & Calmer in self-control & 0,8 & 0,2 & 0,6 & Most likely to & Existential \\
\hline G60 & Firm in trouble & 0,8 & 0,2 & 0,6 & Most likely to & Existential \\
\hline
\end{tabular}

Table Description:

CF: Certainty Factor

MB: Meansure of Believe

MD: Meansure of Disbelieve

Term: The tendency of student talent

Table 1 shows the results of the Certainty Factor calculation of interests and talents agreed by the experts. Some tendencies produce definite, almost certainly, and most likely. The way the AMBA application works using a user login is that the user evaluates the students' interest than the counting process in the system using the Certainty Factor method, after which the tendency results will appear according to the highest percentage produced. For example, if the assessment produces $\mathrm{CF}=0.9513$ then the percentage is $0.9513 * 100 \%$, so the tendency for an aptitude has a value of $95.13 \%$. The highest percentage is the value of interest and talent.

\section{A. Use Case Diagram}

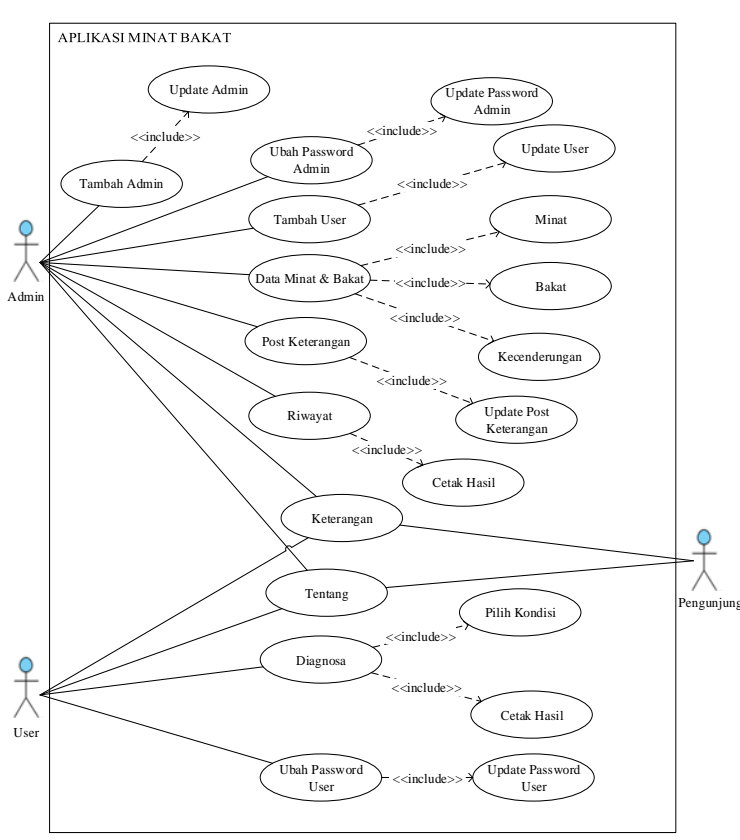

Figure 3 Use Case Diagram AMIBA 
Figure 3 explains that the admin can do a variety of user manage, interests, talents, post information, and history. Users can only assess interests and talents. While the information page and about can be accessed by the admin, user, and visitor.

\section{B. Interface Display}

\section{1. "AMIBA" Interface Display}

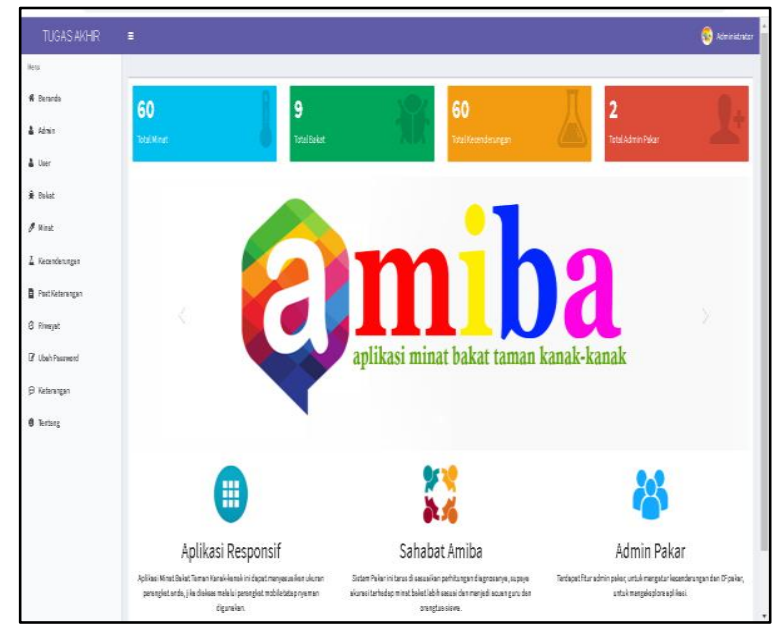

Figure 4 Main Page AMIBA

Figure 4 is an interface display from the application of interests and talents.

\section{Tendency Page Interface Display}

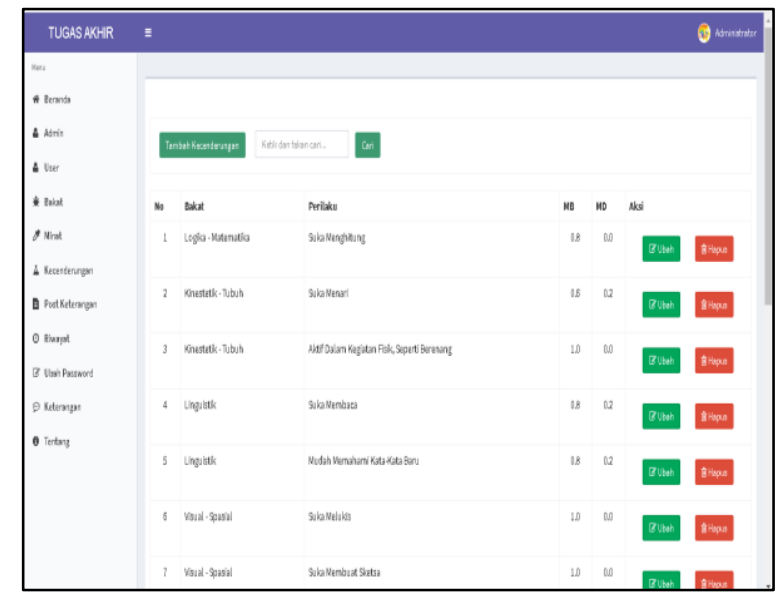

Figure 5 tendency page

Figure 5 is a trend management page, where the admin determines values (MB) and (MD) as calculations (CF)

\section{Assessment page Interface Display}

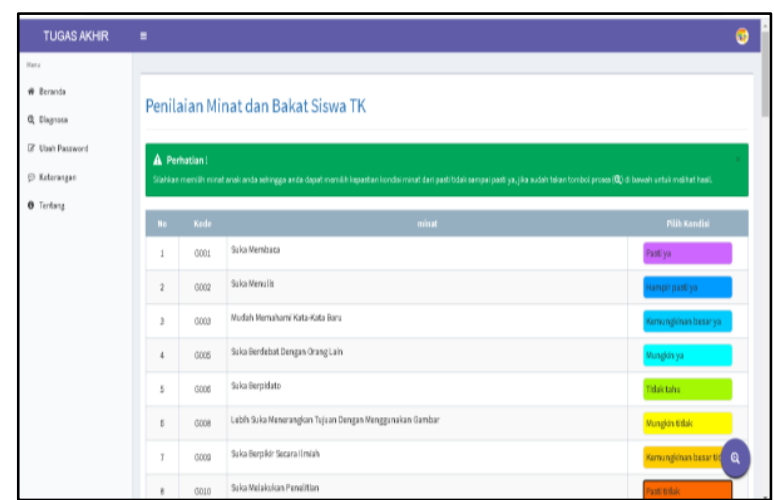

Figure 6 Assessment page

Figure 6 is an appraisal page where the user evaluates interests.

\section{Assessment Results Page Interface Display}

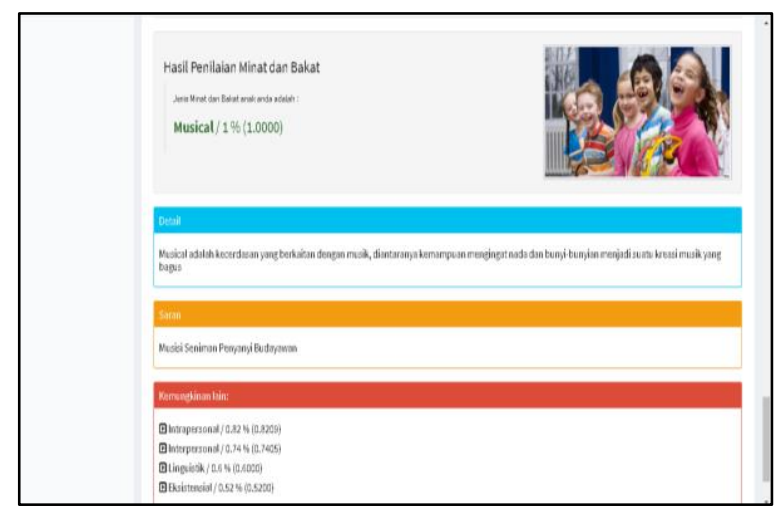

Figure 7 Assessment Results Page

Figure 7 is an assessment result page where the user will get an assessment of a student's interests and talents.

\section{CONCLUSIONS AND SUGGESTIONS}

\section{Conclusions}

Research results that the AMIBA web-based application can assess students' interests and talents. This application is a measuring tool used by teachers to assess the interests and talents of their students.

\section{Suggestions}

Suggestions for future research improvement and development, i.e. (1) this application is still simple, developments further are expected to be more interesting; (2) future development based on Android making it easier to use; (3) Observation of student behavior became a reference for expert 
system judgment; (4) Periodically evaluate the assessment of interests and talents with consult to psychologists and child observers so that the material assessed by the expert system can be updated properly;

\section{REFERENCE LIST}

Andriani, A. (2016). Pemrogrman Sistem Pakar (Tahwin (ed.); 1st ed.). MediaKom.

Ardha, R. Y., Dwi, P., \& Pamungkas, A. (2019). Copyright@2019. P2M STMIK BINA INSANI Pemilihan Paket Travel Dengan Metode Technique for Order Preference by Similiarity to Ideal Sulution (TOPSIS). INFORMATICS FOR EDUCATORS AND PROFESSIONALS, 3(2), 139-148. http://www.ejournalbinainsani.ac.id/index.php/ITBI/article/vie w/1092

Educenter. (2018). Kecerdasan Majemuk, Langkah Awal Menggali Minat dan Bakat Anak. In https://www.educenter.id/kecerdasanmajemuk-langkah-awal-menggali-minat-danbakat-anak/.

Komala. (2017). Stimulasi Melejitkan Potensi, Minat Dan Bakat Pada Anak Usia Dini. Tunas Siliwangi , 3(2), 181-194.

Musfiroh, T. (2014). PAUD4404 - Pengembangan Kecerdasan Majemuk (1 / 3 SKS). Universitas Terbuka.

Rachman, R., \& Mukminin, A. (2018). Penerapan Metode Certainty Factor Pada Sistem Pakar Penentuan Minat dan Bakat Siswa SD. Khazanah Informatika: Jurnal Ilmu Komputer Dan Informatika. https://doi.org/10.23917/khif.v4i2.6828

Salisah, F. N., Lidya, L., \& Defit, S. (2015). Sistem Pakar Penentuan Bakat Anak Dengan Menggunakan Metode Forward Chaining. Jurnal Ilmiah Rekayasa Dan Manajemen Sistem Informasi.

Yulianti, W. (2016). Aptitude Testing Berbasis Case-Based Reasoning Dalam Sistem Pakar Untuk Menentukan Minat Dan Bakat Siswa Sekolah Dasar. Jurnal Teknologi Dan Sistem Informasi Univrab, 1(2), 110-126. https://doi.org/10.36341/rabit.v1i2.28 